Abstracta Iranica Abstracta Iranica

Revue bibliographique pour le domaine irano-aryen

Volume 24 | 2003

Comptes rendus des publications de 2001

\title{
Le soufisme. Trad. de l'anglais par J.-F. Mayer (titre original: Sufism, the essentials, 2000), Paris, Cerf, 2001.
}

\section{Pierre Lory}

\section{OpenEdition}

1 Journals

\section{Édition électronique}

URL : http://journals.openedition.org/abstractairanica/34557

DOI : 10.4000/abstractairanica.34557

ISSN : 1961-960X

Éditeur :

CNRS (UMR 7528 Mondes iraniens et indiens), Éditions de l'IFRI

\section{Édition imprimée}

Date de publication : 15 mai 2003

ISSN : 0240-8910

\section{Référence électronique}

Pierre Lory, «Le soufisme. Trad. de l'anglais par J.-F. Mayer (titre original: Sufism, the essentials, 2000), Paris, Cerf, 2001. », Abstracta Iranica [En ligne], Volume 24 | 2003, document 183, mis en ligne le 05 janvier 2010, consulté le 25 septembre 2020. URL : http://journals.openedition.org/abstractairanica/ 34557 ; DOI : https://doi.org/10.4000/abstractairanica.34557

Ce document a été généré automatiquement le 25 septembre 2020.

Tous droits réservés 


\section{Le soufisme. Trad. de l'anglais par J.- F. Mayer (titre original: Sufism, the essentials, 2000), Paris, Cerf, 2001.}

\section{Pierre Lory}

Sous un volume très ramassé, cet ouvrage expose à destination d'un public non averti l'essentiel de l'histoire et des principes du soufisme, du rôle des courants mystiques au sein de la communauté musulmane, du fonctionnement interne des confréries, de leur vie à l'époque contemporaine. Cet exposé vif et documenté ne fait pas double emploi avec d'autres ouvrages analogues d'introduction à la mystique soufie.

INDEX

Thèmes : 8 . Soufisme

\section{AUTEURS}

PIERRE LORY

EPHE - Paris 